\title{
CONCOMITANT INVOLVEMENT OF THE SMALL INTESTINE AND THE DISTAL ESOPHAGUS IN AN INFANT WITH MASSIVE NECROTIZING ENTEROCOLITIS
}

Uenis Tannuri, Virginia Antelmi Gomes and Eduardo Juan Troster

TANNURI U et al. Concomitant involvement of the small intestine and the distal esophagus in an infant with massive necrotizing enterocolitis. Rev. Hosp. Clín. Fac. Med. S. Paulo 59(3):131-134, 2004.

Necrotizing enterocolitis is a disease of the newborn that may involve the small intestine and/or the colon, and the stomach. To our knowledge, massive necrosis of the small intestine with concomitant involvement of the esophagus has never been reported. A case of a 6-month-old boy with necrotizing enterocolitis and pan-necrosis of the small intestine, cecum, and the lower third of the esophagus is presented. After 70 days of treatment, intestinal transit was established by an anastomosis between the first centimeter of jejunum and the ascending colon. Finally, esophageal transit was established by a total gastric transposition with cervical esophagogastric anastomosis. The patient was maintained under total parenteral nutrition, and after 19 months he developed fulminant hepatic failure due to parenteral nutrition; he then underwent combined liver and small bowel transplantation. After 2 months, the patient died due to undefined neurologic complications, probably related to infection or immunosuppressive therapy.

KEY WORDS: Necrotizing enterocolitis. Esophageal perforation. Total parenteral nutrition. Liver-small bowel transplantation.

Necrotizing enterocolitis (NEC) is a disease of the newborn that may involve the small intestine and/or the colon and the stomach. We present a peculiar case of an infant beyond the neonatal period, with pan-necrosis of the small intestine and the lower third of the esophagus. After esophageal replacement, the child was maintained on total parenteral nutrition, and he then presented a fulminant hepatic failure and underwent combined liver and small bowel transplantation. To our knowledge, massive necrosis with concomitant involvement of the small intestine and esophagus has never before been reported.

\section{CASE REPORT}

C. Y. G., a 6-month-old boy with a previously good nutritional status, presented with a 2-day history of vomiting and fever. On examination, he was in critical condition in a state of shock with abdominal distention. An abdominal paracentesis revealed brown and putrid fluid, and an emergent

From the Pediatric Intensive Care Unit, Albert Einstein Jewich Hospital and Pediatric Surgery Division, Faculty of Medicine, University of São Paulo - São Paulo/SP, Brazil.

E-mail: uenis@usp.br

Received for publication on August 20, 2003. laparotomy was indicated. Extensive involvement with necrosis and perforation of the entire small intestine and cecum was found. The pulse of the superior mesenteric artery could be palpated, so we suspected that the necrosis was caused by peripheral venous thrombosis. Since the patient was in critical condition (state of shock and cardiac arrhythmia) and the necrosis of the entire intestinal wall was found to be irreversible, after an observation period of 1 hour, we decided to resect the entire small intestine and cecum. The only segments that could be preserved were the duodenum, $2 \mathrm{~cm}$ of jejunum, and the colon (excluding the 
cecum). The proximal end of the jejunum was exteriorized, and the abdominal wall was closed by layers.

The postoperative period was complicated by sepsis, respiratory insufficiency, pneumothorax, and a reversible cardiac arrest during the correction of an episode of hypokalemia. During the postoperative treatment, it was noted that a salivary secretion had drained through the chest tube that had been introduced to treat the pneumothorax. Subsequently, a diagnosis of spontaneous (or iatrogenic) perforation of esophagus was suspected and confirmed by radiographic studies. The chest tube was kept to treat the esophageal perforation, and parenteral nutrition and broad-spectrum antibiotics were administered.

The surgery was complicated by necrosis and dehiscence of the jejunostomy, in conjunction with dehiscence of the laparotomy. These complications were conservatively treated by appropriate drainage and total parenteral nutrition.

Seventy days after the initial surgical procedure, the patient underwent another surgery to perform the anastomosis between the first centimeter of jejunum and the ascending colon. A Stamm gastrostomy was additionally performed, and the postoperative period was uneventful.

After 3 months of intensive therapy and total parenteral nutrition, it was noted that salivary secretion persisted through the chest tube. A new esophagogram showed that the proximal two thirds of the esophagus were present and drained to the right pleural cavity and to the chest tube. The distal third of the esophagus could not be visualized (Figure 1). A retrograde endoscopy through the gastrostomy stoma confirmed the destruction of the distal third of the esophagus by the necrosis.

After resecting the proximal thoracic esophagus through a midline su- pra-umbilical laparotomy and performing a left cervicotomy, we established esophageal transit by accomplishing a total gastric transposition with a cervical esophagogastric anastomosis. The postoperative period was uneventful, and on the fourth day the patient started to drink liquids.

Total parenteral nutrition was maintained for 18 months, and it was complicated by 8 episodes of systemic infection and 3 episodes of reversible liver dysfunction. Finally, the patient was transferred toMiami (USA), and 1 month afterwards he presented a fulminant hepatic failure due to parenteral nutrition; he then underwent a combined liver and small bowel transplant.
After 2 months, the patient died due to undefined neurologic complications, probably related to infection or immunosuppressive therapy. Autopsy was not performed.

\section{DISCUSSION}

Necrotizing enterocolitis, although considered to be a disease typical of the premature baby, can also affect the fullterm infant from the first days of life until several months after birth,, ${ }^{1,2}$ especially those with congenital heart disease. ${ }^{3}$ To date, the exact pathogenesis of NEC remains elusive, although 3 major factors-a pathogenic microor-

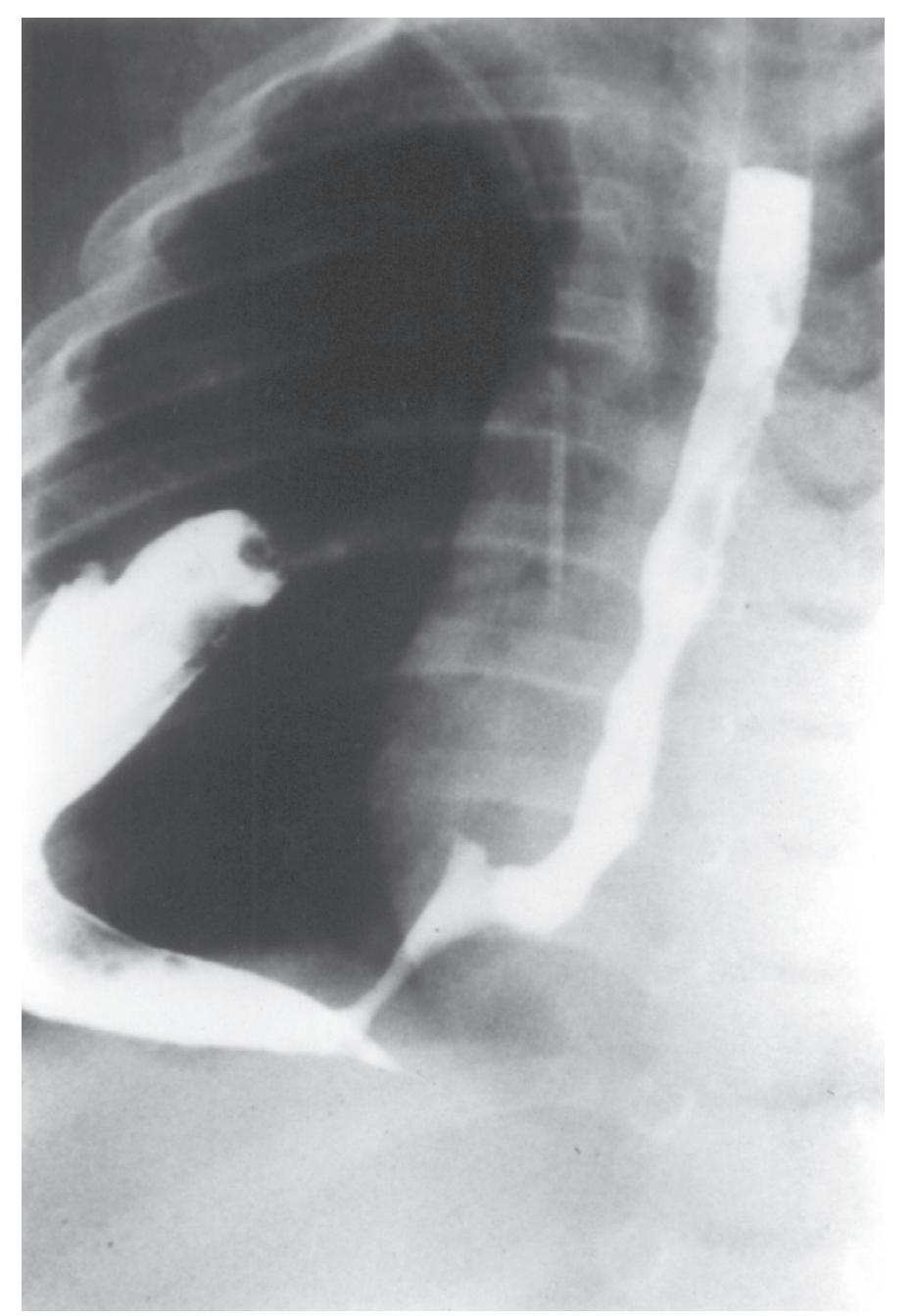

Figure 1 - Esophagogram showing extravasation of the contrast medium into the right pleural cavity. The lower third of the esophagus is not visualized. 
ganism, artificial hyperosmolar enteral diets, and bowel compromise-coalesce in at-risk neonates to produce bowel injury. Initiation of the inflammatory cascade likely serves as a common pathway for the disorder. Clinical signs and symptoms range from mild feeding intolerance with abdominal distension to catastrophic disease with extensive bowel involvement and perforation, peritonitis, and shock, as with the current case ${ }^{4}$.

There are few reports about the incidence of NEC beyond the neonatal period. In contrast with the present case, it has been reported that the affected infant is usually previously undernourished and that this condition contributes to the development of NEC beyond the neonatal period, with a high mortality rate $(90 \%)^{5}$.

It is known that $19 \%$ of patients develop pan-involvement of the intestine with necessity of massive resection that leads to the short bowel syndrome, like in the present case ${ }^{1}$. Since we could not explain the anatomic mechanisms responsible for the concomitant involvement of the small intestine and the distal esophagus, we may suppose that humoral factors responsible for the development of intestinal necrosis also affected the distal esophagus and promoted necrosis of the viscera. There is only 1 similar case reported in the literature about a child with acute necrosis of the esophagus preceded by a necrotizing ileitis due to anaphylactoid purpura, and the authors suggested that humoral factors connected with the baseline disease were probably responsible for the esophageal and small intestine involvement ${ }^{6}$.

The treatment of the child presented in this report was a very complex problem. First, before the intestinal transplant, we had to reconstruct esophageal transit. Total gastric transposition was the chosen procedure, because in our experience, it is technically simple and less prone to surgical complications, ${ }^{7}$ compared with other procedures, such as esophagocoloplasty ${ }^{8}$ or partial gastric transposition with gastric tube ${ }^{9}$. In fact, the child presented an uneventful postoperative period, without any complication.

The second challenge was the intestinal transplantation. Recently, this procedure has been qualified as the standard of care for patients with irreversible intestinal failure, since clinical experience has demonstrated cumulative improvements in survival index rates. Prior to the advent of tacrolimus (FK 506), a potent immunosuppressive drug, uncontrolled rejection, graft-versus-host disease, and fatal infection were responsible for the death of patients. These problems were derived from the large gut lymphoid mass and heavy microbial load contained in the intestinal lumen with the absence of effective immunosuppressive and antimicrobial therapies. With the emergence of small bowel and multivisceral transplantation in 1990, with the effective control of rejection by using tacrolimus and the treatment of life-threatening opportunistic infections with potent antimicrobial agents, the reported overall 1-year patient survival rate has been between $40 \%$ and $70 \%{ }^{10-12}$.

The child in this case study presented another serious and frequent complication of prolonged parenteral nutrition therapy: liver dysfunction. Among children undergoing parenteral nutrition, cholestatic jaundice and liver dysfunction have a complex and undefined etiology. Probably, parenteral nutrition solutions, mainly amino acid solutions, produce deleterious effects on the immature liver. Other risk factors include the absence of enteral nutrition, intestinal stasis, and altered response to sepsis. Finally, it is well documented that infants and children with short bowel syndrome are particularly sensitive to progressive neonatal cholestatic jaundice and liver dysfunction ${ }^{13-17}$.

The final treatment, based on combined liver and small bowel transplantation, was the only life-saving procedure that could be attempted in this case, since the short bowel syndrome and parenteral nutrition-related endstage liver disease were irreversible. Unfortunately, the procedure resulted in death after 2 months due to neurologic complications.

\section{RESUMO}

TANNURI U e col. Acometimento concomitante do intestino delgado e esôfago distal em criança com enterite necrosante maciça. Rev. Hosp. Clín. Fac. Med. S. Paulo 59(3):131-134, 2004.

A enterite necrosante é uma doen- ça típica do período neo-natal que pode acometer o intestino delgado, colo e/ou estômago. Até o presente, a necrose maciça do intestino delgado com o acometimento concomitante do esôfago nunca foi relatada. É apresentado o caso de um lactente com 6 meses de idade com enterite necrosante e acome- timento de todo intestino delgado, ceco e terço inferior do esôfago. Após setenta dias de tratamento, o trânsito intestinal foi re-estabelecido por anastomose entre o primeiro centímetro do jejuno e o colo ascendente. Finalmente, o trânsito esofagiano foi refeito pela transposição gástrica total e anastomose 
esôfago-gástrica cervical. O paciente foi mantido em nutrição parenteral durante 19 meses e ao fim deste período desenvolveu falência hepática aguda, tendo sido submetido a transplante duplo de fígado e intestino delgado. Dois meses após, faleceu em decorrência de complicações neurológicas, provavelmente relacionadas à infecção ou ao tratamento imunossupressor.
UNITERMOS: Enterite necrosante. Perfuração de esôfago. Nutrição Parenteral Total. Transplante de fígado e intestino.

\section{REFERENCES}

1. Grosfeld JL, Cheu H, Schlatter M, West KW, Rescorla FJ. Changing trends in necrotizing enterocolitis. Experience with 302 cases in two decades. Ann Surg 1991; 214:300-6.

2. Mancila-Ramirez J, Vera-Castro F, Martinez-Hernandez FJ.Frequency of neonatal necrotizing enterocolitis at a pediatric hospital. Bol Med Hosp Infant Mex 1989; 46:485-493.

3. Ostlie DJ, Spilde TL, St Peter SD, Sexton N, Miller KA, Sharp RJ et al. Necrotizing enterocolitis in full-term infants. J Pediatr Surg 2003; 38:1039-1042

4. Kafetzis DA, Skevaki C, Costalos C. Neonatal necrotizing enterocolitis: an overview. Curr Opin Infect Dis 2003; 16:349355 .

5. Degan R, Bem-Yacov O, Mares AJ Moses SW, Bar-Ziv J. Necrotizing enterocolitis beyond the neonatal period. Eur J Pediatr 1984; 142:56-8.

6. Weisberger G, Sonsino E, Hayat P, Bourillon A, Lecointre C, Boureau M. Acute necrosis of the thoracic esophagus and ileum complicating rheumatoid purpura. Arch Fr Pediatr 1979; 36:194-8.

7. Marujo WC, Tannuri U, Maksoud JG. Total gastric transposition: an alternative to esophageal replacement in children. J Pediatr Surg 1991; 26:676-682.

8. Tannuri U, Maksoud-Filho JG, Maksoud JG. Esophagocoloplasty in children: surgical technique, with special emphasis to the double blood supply to the interposed colon, and results. J Pediatr Surg 1994; 29:1434-1440.

9. Tannuri U, Maksoud JG. Substituição Cirúrgica do Esôfago. In: Maksoud JG. Cirurgia Pediátrica. $2^{\text {nd }}$ ed. Rio de Janeiro, Revinter, 2003. p. 543.
10. Langnas A, Chinnakotla S, Sudan D, Horslen S, McCashland T, Schafer D et al. Intestinal Transplantation at the University of Nebraska Medical Center: 1990 to 2001. Transpl Proceed 2002; 34:958-960.

11. Kato T, Nishida S, Mittal N, Levi D, Nery J, Madariaga J et al. Intestinal Transplantation at the University of Miami. Transpl Proceed 2002; 34:868.

12. Nishida S, Levi D, Kato T, Nery JR, Mittal N, Hadjis N_et al. Ninety-five cases of intestinal transplantation at the University of Miami. J Gastrointest Surg 2002; 6:233-9.

13. Teitelbaum DH, Tracy T. Parenteral nutrition-associated cholestasis. Sem Pediatr Surg 2001; 10:72-6.

14. Moss RL, Das JB, Ansari G, Raffensperger JG - Hepatobiliary dysfunction during total parenteral nutrition is caused by infusate, not the route of administration. J Pediatr Surg 1993; 28(3):391-6.

15. Chan S, MCcowen KC, Bistrian BR, Thibault A, Keane-Ellison $\mathrm{M}$, Forse RA et al. Incidence, prognosis, and etiology of endstage liver disease in patients receiving home total parenteral nutrition. Surgery 1999; 126:28-34.

16. Simmons MG, Georgeson KE, Figueroa R, Mock DL 2nd. Liver failure in parenteral nutrition-dependent children with short bowel syndrome. Transplant Proc. 1996; 28: 2701.

17. Meehan JJ, Georgeson KE. Prevention of liver failure in parenteral nutrition-dependent children with short bowel syndrome. J Pediatr Surg 1997; 32:473-5. 